\title{
INFLUENCE OF THE SOVIET GOVERNMENT'S POLICY OF "KULAK" AND REPRESSION ON UZBEK WOMEN
}

\author{
Aziza Nigmanovna Akhrorova \\ Head of the Department of Guides of the State Museum of Repression Victims, Tashkent, \\ Republic of Uzbekistan
}

Article DOI: https://doi.org/10.36713/epra9302 DOI No: $10.36713 /$ epra9302

\begin{abstract}
This article discusses the negative effects of the Soviet government's "kulak" and repressive policies on Uzbek women. The Covet government, by organizing training courses, trained women; involved women in social life in exchange for the sacrifice of hundreds of women. At the same time, the above-mentioned policy of kulak and repression has led to the suffering of Uzbek women as well as men. Below we meet some of these women.
\end{abstract}

KEY WORDS: repression policy, kulak, austerity policy, sentence, imprisonment, criminal code, People's Commissariat of Internal Affairs, counter-revolutionary activity, family, Uzbek woman.

\section{INTRODUCTION}

Thanks to independence, the period of Soviet rule in the history of Uzbekistan began to find a new, scientifically objective and just solution. This is especially evident in the study of the history of the Soviet period, which has been falsified and biased for decades. At the same time, the attitude of the Soviet government towards women is one of the problems that need to be addressed. As the policy of the Soviet totalitarian regime in Uzbekistan on women's issues is inherently contradictory, the main task today is to objectively cover the historical reality on a scientific basis with the help of archival documents and sources. This explains the urgency of the problem.

The study focuses on the nature of Soviet-era policies toward women. During this period, the Soviet Union's colonial policy, led by the Communist Party, was based on a command-andcontrol approach to women. scientific analysis of the tragic consequences of mass repressions is one of the most pressing issues in the study of history.

\section{LITERATURE REVIEW}

Soviet-era research has largely praised the role of pseudo-communist ideology as a "revolutionary transformer" in socio-political, economic, and spiritual life. illuminated in terms of. The great statehood and chauvinist policies of the dictatorial regime were glorified, and the ideas of Marxism-Leninism, which were alien to the Uzbek people, were propagated. The basis of the literature of the Soviet period was the idea of the struggle against traditional national and religious values, which have been formed over the centuries and have become the way of life, the spiritual image of women in the East. The literature of the Soviet period was written in the style of a single political ideology, and very important issues were falsified. The essence of the literature of the totalitarian regime was an unscientific conclusion that the issue of women was "solved" and the essence of "women's freedom" was analyzed in terms of the goals and interests of the Communist Party [13].

In the first years of independence, D.A. Alimova's scientific monograph and a number of scientific articles on the history of Central Asian women, her doctoral dissertation were the first step in revealing the colonial nature of Soviet policy towards women [3]. The historian's article on traditional views on the status of women in the family and the interpretation of historical truth [2] first highlighted the various social views on the subject and their historical roots on a scientific basis.

M. Tokhtakhodjaeva's book, Women of the Past, which focuses on women's issues, argues that the improvement in the situation of women has only 


\section{EPRA International Journal of Research and Development (IJRD)}

\author{
Volume: 7 | Issue: 1 | January 2022
}

- Peer Reviewed Journal a positive effect on society. She writes, “... that today women are still striving for the social, economic, political, and spiritual spheres of society, and no one has chosen a business in which women are now fully realizing their intellectual and educational potential" [12].

Ya. Abdullaeva's special monograph and articles on the lives of women in Karakalpakstan, Women of Karakalpakstan: Yesterday and Today (Late 19th and 20th Centuries), should be noted, as they provide scientific conclusions and extensive information based on archival documents. - made a worthy contribution to the study of the issue of girls in historical terms [1].

The play "Exile" tells the story of Uzbek families who were deported to Ukraine. There are stories of people who saw those processes with their own eyes, who were directly involved in the process. This book also describes the lives of women in exile [11].

\section{RESEARCH METHODOLOGY}

Primary, archival documents, were used to cover the research. In addition, the children of the persecuted were covered based on the information of their grandchildren. The method of "oral history" was used.

The problem was studied by N.Karimov, H.Ahrorova, Sh.Turdiev on the basis of archival materials, and the main part of their articles was published in the collection of articles and essays "Tulips in the Snow" (2001). The play "Exile" talks about the process of deafness and its consequences. The documentary "Flower in the Rain" (1986) by Y.Sulaymon is based on an interview with the protagonist of the story - a victim of repression Tajikhon Shodieva.

A number of studies have been conducted in our country on the topic of women, but the topic of repressed women has not been widely covered and not brought to the level of a dissertation. This study seeks to shed light on the issue of repressed women based on primary sources. In order for these women to take their rightful place in the pages of history, efforts must be made to pass them on to the next generation.

In the early 1930s, when the process of "kulak" began in the village, not only well-to-do peasants with property, but also middle and, in some cases, people from poor farms were deported. As a result of land and water reform, about 255,000 desiatins of land have been created in Tashkent, Fergana, Samarkand and Zarafshan regions. Seventy percent of these lands were taken from the rich, and the remaining 30 percent were lands of newly developed lands, state property, foundations, and other strata. In the process of reform, 2603 farms in
Tashkent, Samarkand, Fergana and Zarafshan regions were recognized as kulak farms. Land deemed "surplus" was confiscated from 22,871 farms. [10]

The "kulaks" of Central Asia began to be exiled from their lands in the spring of 1930. The ears were mainly exiled to the North Caucasus, Ukraine, Kazakhstan, the Far East, Siberia, the Urals. The victims of the "kulak" campaign were deprived not only of their property and homes, but also of their right to vote and stand for election, as well as their passports, and lived under commandant's control. The life of the "kulaks" was extremely difficult, and the material provision, medical care, and living conditions were very bad. They lived mainly in barracks, capes and basements. The Uzbek "kulaks" apparently grew up in sunny lands and adapted to field work. Therefore, some of them died in the Kherson region, Stavropol Territory, especially in northern Kazakhstan, unable to withstand the frosty winter and suffering from cold and starvation. In particular, the Uzbeks deported to the 37th labor settlement in the Shartandin district of Northern Kazakhstan suffered from a lack of bread, unable to meet their daily norms in the performance of unconventional work, except in extreme cold. Their requests for relocation to warmer countries went unheeded.

In exile, the "kulaks" were mainly engaged in the development of new lands, drainage of swamps, clearing of forests, fisheries, road construction, digging canals, farming. In Ukraine, they were used to develop cotton. From January 1, 1930 , to July $1,1931,6,159$ of the $1,210,000$ peasant farms in Central Asia were exiled as "kulak" farms [4].

Below we provide information about some of the women in exile.

Exiled woman in Ukraine: Khosiyat Suleymanova was deported with her children in 1930 with her family. His wife, Mavlon Suleymanov, was repressed and shot on June 10, 1938. After World War II, he returned to Uzbekistan with his sons Sultanmurod and Mirzamurod.

Women deported to the North Caucasus:

Salovat Asadova was deported from the village of Tanishka, Samarkand region.

Khosiyatkhon Yormuhammedova was exiled from Kattakurgan district of Samarkand region in 1931 with her family members. He returned to Uzbekistan in 1946.

Exiles to labor settlements in Central Asia:

Ogiljon Doniyorova was born in 1930 in the village of Arabkhona, Romiton district, Bukhara region. In May 1932, his father Kurbanov Doniyor and his family were exiled to the Savay state farm. He was released on July 17, 1952. 


\title{
EPRA International Journal of Research and Development (IJRD)
}

\author{
Volume: 7 | Issue: 1 | January 2022 - Peer Reviewed Journal
}

Adolat Shukurova was born in 1887 in Romitan district of Bukhara region. In 1932, he and his son Alim Shukurov were exiled to the Savay state farm in Andijan region. Released in 1952.

Azamatkhon Sodikova and her family were exiled in 1932 to the labor settlement "Savay" in Forish district, Jizzakh region.

Aisha Kholikova (1901) was exiled in 1932 to the state farm "Savay" in Pastdorgom district, Samarkand region. He was released in March 1952.

Aziza Lukmanova (born in 1899) was exiled in 1932 from Poyarik district of Samarkand region to the 9th department of the state farm "Savay". Released in March 1952.

Mukarram Kochimova (born 1899) was exiled with her son to the labor camp in Izboskan, Kattakurgan district, Samarkand region, 1932. In July 1952 she was released from labor exile.

Haitkhon Shahobiddin qizi was exiled from Jalal-Abad in 1932 to Yangiyul labor settlement together with her father Shahobiddin Akhunjanov. In 1948 he returned to Jalalabad [5].

We have already seen the impact of the Soviet government's "kulak" policy on Uzbek women. Let us now turn our attention to the impact of the policy of repression on Uzbek women in 19371938. The sharp edge of the sword of repression did not bypass not only the state, literature and science, but also women. They, like their spouses, were arrested innocently. Their children were taken to an orphanage. These measures were taken in accordance with the order of the USSR People's Commissariat of Internal Affairs of August 15, 1937 No 00486 “On measures to repress the wives and children of traitors". Here are some of the women who were persecuted:

Hasanova Rokhil Qiyomovna was born in 1907 in Tashkent. Tatar. Housewife. Arrested on August 15, 1937 by the NKVD. Accused of counterrevolutionary activity. On February 8, 1939, he was suspended for not proving guilt [6].

Islamova Elmira Suleymanovna was born in 1917 in Tashkent. Kazakh. Student. On October 30, 1937, he was arrested by the NKVD. Accused of counter-revolutionary activity. He was released on February 15, 1939, on the grounds that his guilt had not been proven [7].

Solikhova Karima was born in 1892 in Tashkent. Uzbek. Housewife. On November 23, 1937, he was arrested by the NKVD. Accused of counter-revolutionary activity. He was released on February 5, 1939, without charge [8].

Inoyatova Khayri was born in 1894 in Tashkent. Uzbek. Housewife. On October 14, 937, he was arrested by the NKVD. Accused of counterrevolutionary activity. He was released on December
13, 1938, on the grounds that his guilt had not been proven [9].

\section{CONCLUSION}

From the above, it can be seen that the illegal, inhumane policy of the Soviet government towards the local people did not bypass not only the local men, but also their wives and children. The names of these women should be given a worthy place in the pages of history, along with their spouses.

\section{REFERENCES}

1. Abdullaeva Ya.A. Women of Karakalpakstan: Yesterday and today. The end of the XIX century and the XX century. - Tashkent: The world of creativity. 2004. - $224 p$.

2. Алимова Д.А. $\mathrm{Mbl}$ не должны быть обществом, пропитанным идеей превосходства мужчин //Ташкентская правда. - 1997 г.,26 март.

3. Alimova D.A. Women's question in Central Asia: History of study and modern problems.-Tashkent, Fan, 1991; Alimova D.A. The study and problems of women in the social sciences of Uzbekistan // The role of women and gender issues in the construction of the family, state and society in Uzbekistan. - Tashkent, Fan, 1999. - P.16-20.

4. Archive of the State Museum in memory of the victims of repressions

5. Archive of the State Museum in memory of the victims of repressions.

6. Archive of the State Museum in Memory of the Victims of Repressions.P-8364.

7. Archive of the State Museum in memory of the victims of repressions. P-7746.

8. Archive of the State Museum in memory of the victims of repressions.P-8089.

9. Archive of the State Museum in memory of the victims of repressions.P-15652.

10. 10.Rustambek Shamsutdinov. Soviet policy of deafness in Uzbekistan and its tragic consequences. -Tashkent: "Shark", 2001. p. 5859.

11. Surgun. -Tashkent. 2000. Page 5

12. Tukhtakhujaeva M. Women tired of the past. The return of society to Islam in Uzbekistan and the situation of women. Published by the Regional Program Office. - Tashkent: 2002. - P.19.

13. Yakubova H. Women of Soviet Uzbekistan. Tashkent: United publishing house "Pravda Vostoka" and "Kizil of Uzbekistan", 1947; Rakhimbabayeva Z. Female of Uzbekistan on the way to communism. - Tashkent: State Publishing House of UzSSR, 1949. 